\title{
Mesenchymal stem cells in periodontics: new perspectives
}

\author{
Células mesenquimais indiferenciadas em periodontia: novas perspectivas
}

\author{
Bruna Rabelo AMORIM ${ }^{1}$ \\ Enilson Antonio SALLUM² \\ Marcio Zaffalon CASATI ${ }^{2}$ \\ Karina Gonzales Silverio RUIZ² \\ Renato Correa Viana CASARIN² \\ Kamila Rosamilia KANTOVITZ ${ }^{3}$ \\ Francisco Humberto NOCITI JUNIOR ${ }^{2}$
}

\begin{abstract}
Tissue engineering is a contemporary field of science, which aims to create conditions based on principles of cell and molecular biology bioengineering and biomaterials to regenerate tissues. Mesenchymal stem cells present high proliferation rates and are able to differentiate into multilineages under certain conditions, suggesting that they have great potential to act in regeneration field. Tooth derived stem cells are a suitable alternative source of mesenchymal cells once they are easily accessible and have poor morbidity to the donor. Studies showed that they have been isolated and characterized from diverse tissues such as dental pulp, exfoliated deciduous teeth, periodontal ligament, gingiva, dental follicle and apical papilla. However studies show that there is heterogeneity among these populations and there is no standard method to select the most appropriate tooth derived stem cells for regenerative procedures. The aim of this review is to present the current perspective of the multiple types of tooth-derived stem cells and to discuss the basis for their use in periodontal tissue engineering.
\end{abstract}

Indexing terms: Periodontics. Stem cells. Tissue engineering.

\section{RESUMO}

A engenharia de tecidos é um campo contemporâneo da ciência, que visa criar condições baseadas em princípios de biologia celular e molecular, bioengenharia e biomateriais para regenerar tecidos. As células tronco mesenquimais apresentam altas taxas de proliferação e são capazes de se diferenciar, sob certas condiçôes, em multi-linhagens, sugerindo que elas têm grande potencial para atuar no campo da regeneração. As células tronco derivadas de tecidos dentais são uma fonte alternativa adequada de células mesenquimais uma vez que são de fácil acesso e têm baixa morbidade para o doador. Estudos demonstraram que elas já foram isoladas e caracterizadas a partir de diversos tecidos tais como polpa dentária, dentes decíduos esfoliados, ligamento periodontal, gengiva, folículo dental e papila apical. Entretanto, os estudos demonstram que há heterogeneidade entre essas populações e não existe um método padrão para selecionar as células-tronco dentais mais apropriadas para procedimentos regenerativos. O objetivo desta revisão é apresentar o conhecimento atual dos vários tipos de célulastronco derivadas de dentes e discutir as novas perspectivas para seu uso na engenharia de tecidos periodontais.

Termos de indexação: Periodontia.Células-tronco. Engenharia tecidual.

\section{INTRODUCTION}

Tissue engineering is an emerging field, which aims to guide formation, repair, and vascularization of organs by using biological and physical principals. The basic components for tissue engineering involve the interaction of three factors: scaffolds, signaling molecules, and cells. This interactive triad targets the production of functional and biocompatible conditions for tissue regeneration'. Stem cells (SCs) are an increasing subject once they are a way to regenerate injured tissues and should improve the treatment of some illness that so far has no resolution such as diabetes and Parkinson's disease. They can be obtained from earliest stages of development to adult stage ${ }^{2-3}$. Embrionic SCs are a pluripotent cell type which can differentiate into all cells of the body but ethical issues like the using of human embryos for research purpose prevents further development in the field, thus Adult SCs are the cell choice for investigation. They have differentiation abilities but it is restricted to some cell types. Mesenchymal stem cells (MSCs) are included on this group ${ }^{4-5}$.

MSCs are widely studied within the medical field because of their therapeutic potential. They present high proliferation rates and can be induced to differentiate into multiple lineages ${ }^{2}$. These populations are very heterogeneous once there is no defined marker to identify mesenchymal stem cells ${ }^{6}$. International Society for cell

\footnotetext{
${ }^{1}$ Universidade de Brasília, Faculdade de Saúde, Laboratório de Histopatologia Bucal. Asa Norte, 70910900, Brasília, DF, Brasil. Correspondência para / Correspondence to: BR AMORIM. E-mail: <brunaamorim@unb.br>

${ }^{2}$ Universidade Estadual de Campinas, Faculdade de Odontologia, Departamento de Prótese e Periodontia. Piracicaba, SP, Brasil.

${ }^{3}$ Faculdade São Leopoldo Mandic, Curso de Odontologia. Campinas, SP, Brasil.
} 
therapy proposed a minimal criteria to define mesenchymal stem cells phenotype, which include be plastic adherent in standard cutures, expression of CD 105, CD 73 and CD 90 but not CD45, CD34, CD14 or CD11b, CD79a or CD19; major histocompatibility complex class II surface molecules and the potential to differentiate into osteoblasts, adipocytes and chondroblasts. Also they must present fibroblast-like spindle shape in culture ${ }^{7}$. Dental tissues are a good alternative source of MSCs, once they are easily accessible with insignificant or no morbidity of the donor site. Various types of tooth-derived stem cells (TDSCs) have been isolated from dental tissues, which include dental pulp ${ }^{8-12}$, exfoliated deciduous teeth ${ }^{13-17}$, periodontal ligament, dental follicle ${ }^{18-20}$, apical papilla ${ }^{21-24}$, periodontal ligament of deciduous teeth ${ }^{14-15,25-27}$ and gingival tissue stem cells ${ }^{28}$. This review article proposes to summarize the literature regarding the current knowledge about stem cells from dental tissue, and their potential in regenerative therapy.

\section{TOOTH DERIVED STEM CELLS (TDSCS)}

Variable methodologies are used to isolate and characterize TDSCs. A summary is represented in Table 1.

Table 1. Characterization of tooth:derived stem cells.

\begin{tabular}{|c|c|c|c|c|}
\hline TDSCs & Location & Positive markers & Negative markers & Differentiation capacity \\
\hline DPSCs & $\begin{array}{l}\text { Permanent } \\
\text { tooth pulp }\end{array}$ & $\begin{array}{c}\text { CD29, CD44, } \\
\text { CD73, CD90 } \\
\text { CD 105, } \\
\text { CD146, } \\
\text { STRO11, Oct } \\
\text { 3/4, Sox2, } \\
\text { nanog }\end{array}$ & $\begin{array}{c}\text { CD 14, CD 34, } \\
\text { CD } 54\end{array}$ & $\begin{array}{l}\text { Osteoblast, adipocyte, } \\
\text { chondrocyte, hepatocyte, } \\
\text { neuron, endothelial like } \\
\text { cells, smooth muscles } \\
\text { cells }\end{array}$ \\
\hline SHED & $\begin{array}{l}\text { Deciduous } \\
\text { tooth pulp }\end{array}$ & $\begin{array}{c}\text { CD 29, CD } \\
\text { 105, CD 146, } \\
\text { STRO } 11\end{array}$ & CD 31, CD 34 & $\begin{array}{l}\text { Osteoblast, odontoblast, } \\
\text { adipocyte, neural cell }\end{array}$ \\
\hline SCAP & Apical papilla & $\begin{array}{c}\text { CD 24, CD } \\
\text { 29, CD 31, } \\
\text { CD 44, CD } \\
\text { 73, CD 90, } \\
\text { CD 105, CD } \\
\text { 106, CD 146, } \\
\text { CD 166, } \\
\text { STRO1, Oct } \\
\text { 3/4, Sox } 2, \\
\text { nanog, } \\
\text { survivin }\end{array}$ & $\begin{array}{l}\text { CD 14, CD 18, } \\
\text { CD 34, CD, } \\
45, C D 150\end{array}$ & $\begin{array}{c}\text { Osteoblast adipocyte } \\
\text { chondrocyte, hepatocyte, } \\
\text { neuron, odontoblasts }\end{array}$ \\
\hline DFPCs & Dental follicle & $\begin{array}{l}\text { CD 29, CD } \\
44, C D, 73 \\
\text { CD 90, CD } \\
\text { 105, nestin }\end{array}$ & $\begin{array}{l}\text { CD } 14, \text { CD } 31 \\
\text { CD } 34, \text { CD } 45 \\
\text { CD } 117\end{array}$ & $\begin{array}{c}\text { Osteoblast, adipocyte, } \\
\text { chondrocyte, hepatocyte, } \\
\text { neuron }\end{array}$ \\
\hline PDLSCS & $\begin{array}{l}\text { Permanent } \\
\text { tooth } \\
\text { periodontal } \\
\text { ligament }\end{array}$ & $\begin{array}{l}\text { CD 44, CD } \\
90, \text { CD 105, } \\
\text { CD 166, CD } \\
146, \text { STRO } 11 \\
\text { Oct 3/4, Sox2, }\end{array}$ & $\begin{array}{l}\text { CD 14, CD 34, } \\
\text { CD45 }\end{array}$ & $\begin{array}{l}\text { Osteoblast/cementoblast, } \\
\text { adipocyte, neuron, } \\
\text { choncrocytes, endothelial } \\
\text { like cells }\end{array}$ \\
\hline & & $\begin{array}{l}\text { nanog, } \\
\text { nestin }\end{array}$ & & \\
\hline
\end{tabular}




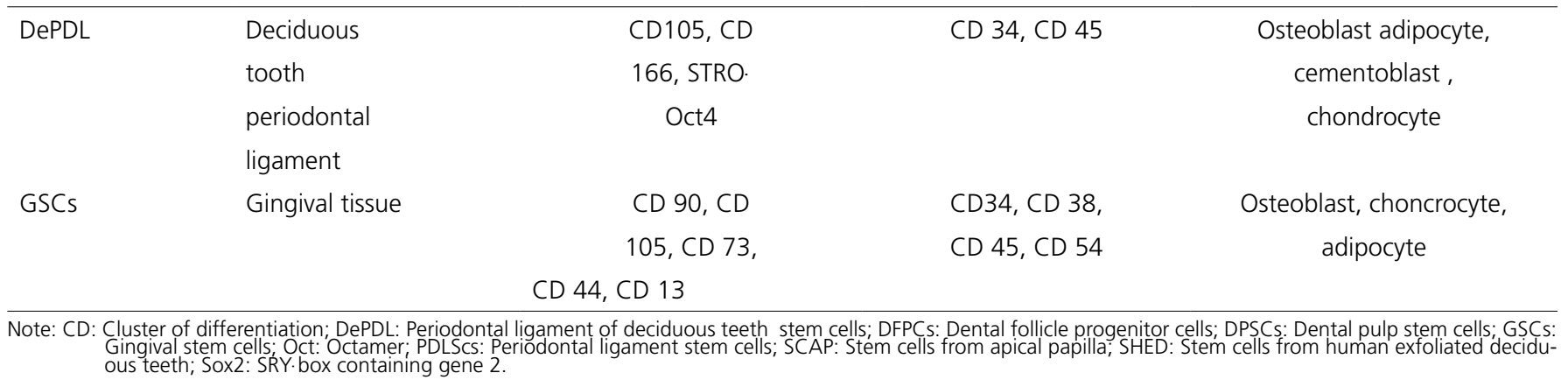

\section{Dental Pulp Stem Cells (DPSCs)}

In 2000, Gronthos and collaborators were the pioneers on isolation and characterization of DPSC, the first TDSC $s^{8}$. When compared with human bone marrows stem cells (BMSCs), DPSCs showed higher proliferation rate and greater capacity to form mineral nodules, so they are more appropriate for regeneration of mineralized tissues than BMSCs. They are able to differentiate into osteoblast, smooth muscle cells, adipocyte-like cells, neuron, dentin, dentin-pup-like complex and endothelial like cells ${ }^{8,29}$.

\section{Stem cells from human exfoliated deciduous teeth (SHED)}

SHEDs are progenitor cells first isolated in 2003, from the remnant pulp of exfoliated deciduous teeth ${ }^{13}$. They showed a higher proliferative rate, when compared to BMSCs and DPSCs ${ }^{13,15}$, and a higher capability to differentiate in osteoblast and adipocyte-like cells when compared to DPSCs in vitro ${ }^{15}$. They also showed the capability do differentiate into odontoblast, neural cells ${ }^{15,30,}$.

\section{Stem cells from apical papilla (SCAPs).}

SCAPS are cells isolated from apical papilla located on the root apex of developing teeth ${ }^{31}$. It is distinct from the pulp tissue ${ }^{32}$. They presented a higher proliferation, migration and telomerase activity. They are able to differentiate into osteoblastic, odontoblastic, adopocyte - like and neuron-like cells under specific induction ${ }^{22}$. A cDNA microarray profiled comparative analysis between SCAP and DPSCs concluded that genes such as CD24 and survivin were highly expressed in SCAPS ${ }^{22}$.

\section{Dental follicle progenitor cells (DFPCs)}

DFPCs are cells obtained from dental follicle which is a condensation of cells originated from the ectomesenchyma that surrounds the tooth germ in early stages of tooth formation. It contains a heterogenic cell population that forms the periodontium ${ }^{18,33}$. They can differentiate into osteoblast, adipocyte, chondrocyte and neuronal cells, but they present differences on proliferation and mineralization patters which suggests that they could commit in distinct lineages ${ }^{33}$.

\section{Periodontal ligament stem cells (PDLSCs)}

PDLSCs are a heterogeneous cell population with neural crest cell origin. They have higher proliferation rate but forms less mineralized nodules when compared to BMSCs. They present the ability to differentiate into osteoblasts, cementoblasts, adipocytes, chondrocytes and endothelial like cells. In vivo experiments confirmed the ability to form periodontal ligament and cementum-like tissue $^{34}$.

\section{Decidous periodontal ligament cells (DePDL)}

Periodontal ligament cells also can be isolated from decidous teeth. It showed higher proliferative rate than PDLSCs, and share the same ability of differentiate into osteoblasts, cementoblasts, adipocytes and chondrocytes, but with a higher potential to differentiate into adipocytes ${ }^{25}$.

\section{Gingival tissue Stem cells (GSCs)}

GSCs are obtained from gingival connective tissue, so the sample must be deepithelialized, to leave only connective tissue. They are able to differentiate into osteogenic, chondrogenic and adipogenic lineages. It also present an immunemodulatory capacity ${ }^{28}$.

\section{Induced pluripotent stem cells (iPSCs)}

iPS cells are derived from somatic cells via transduction and expression of selective transcripition factors. They can differentiate into all derivatives of the 3 primary germ layers $\mathrm{s}^{35}$. They can be obtained from stem cells of apical papilla, dental pulp, exfoliated deciduous teeth stem cells, gingival, periodontal ligament and buccal mucosa fibroblast. They have the ability to differentiate into mesenchymal stem cells, neural crest-like cells, ameloblastlike cells, odontoblast-like cells and osteoprogenitor like 
cells. Although iPS cells are an option without any ethical concerns and it has a great potential towards regeneration of periodontal ligament, alveolar bone, cementum and dentin-pulp complex, issues like epigenetic memory, viraltransduction, tumorgenesis and teratoma formation has to be further investigated ${ }^{35}$.

\section{REGENERATIVE APPLICATIONS OF TDSCS}

Basic components for tissue engineering includes scaffolds, signal molecules and cells. Scaffolds are tridimensional structures, which mimics the extracellular matrix and must have physical, chemical and biological characteristics to provide a microenvironment for cell signaling activation, and stimulation of cellular growth, differentiation, cell adhesion and migration. The cells provide synthesis of extracellular matrix and tissue regeneration. MSCs presents important characteristics such as high proliferation rates and ability to differentiate into multilineages, therefore they have a great potential into tissue engineering field.

Increasing amount of research presents TDSCs applicability in diverse conditions, including myocardial infarction ${ }^{36}$, ischemic disease ${ }^{37}$, neural regeneration ${ }^{38}$, inflammatory diseases ${ }^{39}$, diabetes ${ }^{40}$, muscular dystrophy ${ }^{41}$, bone and cartilage defects ${ }^{42}$, hair follicle loss $^{43}$, skin injuries ${ }^{44}$, salivary gland defects ${ }^{45}$, corneal reproduction ${ }^{46}$, and the regeneration of dental tissues ${ }^{12,22,35,47-49}$.

Several studies demonstrated that TDSCs have successfully regenerated dental tissues such as dentin, pulp and periodontal ligament 12,22,47-49. In vivo experiments demonstrated that human PDLSCs and SCAP were able to generate periodontal ligament in minipigs ${ }^{22}$. Also DPSCs promoted complete pulp regeneration in dogs ${ }^{12}$. Combination of iPS cells with silk scalffold and enamel

\section{REFERENCES}

1. Saito MT, Silvério KG, Casati MZ, Sallum EA, Nociti Jr FH. Toothderived stem cells: Update and perspectives. World J Stem Cells. 2015;7(2):399-407. doi: 10.4252/wjsc.v7.i2.399

2. Kaukua N, Shahidi MK, Konstantinidou C, Dyachuk V, Kaucka $\mathrm{M}$, Furlan $\mathrm{A}$, et al. Glial origin of mesenchymal stem cells in a tooth model system. Nature. 2014;513:551-54. doi: 10.1038/ nature 13536

3. Gothard D, Roberts SJ, Shakesheff KM, Buttery LD. Engineering embryonic stem-cell aggregation allows an enhanced osteogenic differentiation in vitro. Tissue Eng Part C Methods. 2010;16:583595. doi: 10.1089/ten.TEC.2009.0462 matrix promoted PDL regeneration in mouse periodontal fenestration defects ${ }^{35}$.

Although the literature confirms the potential of TDSCs in regeneration, there are some aspects that must be discussed. First, proliferation capacity, clonogeniticy and differentiation ability are different from each type of TDSCs lineages suggesting that it has an association with the type of original tissue. Even in the same population there are heterogeneous cell subpopulation with different behavior ${ }^{50}$. Notwithstanding that International Society for cell therapy defined a minimal phenotype criteria for MSCs, specific surface markers associated with TDSCs commitment are not established.

\section{CONCLUSION}

Interest in regeneration topic has increased inside scientific community. TDSCs are potential actors for regenerative procedures once they are an easy available source that presents almost no morbidity to the donor. Studies, which used TDSCs for regeneration, presented promising results. However, MSCs populations obtained from dental tissues are heterogeneous and, currently, there is no standard method to select the most appropriate TDSCs for regenerative procedures. Further studies must be designed to confirm TDSC-based therapies as safe, predictable and reproducible.

\section{Collaborators}

BR AMORIM, EA SALLUM, MZ CASATI, KGS RUIZ, RCV CASARIN, KR KANTOVITZ and FH NOCITI JUNIOR participated in all stages of the preparation of the manuscript.

4. Watt FM, Driskell RR. The therapeutic potential of stem cells. Philos Trans R Soc Lond B Biol Sci. 2010;365:155-63. doi: 10.1098/ rstb.2009.0149

5. Fischbach GD, Fischbach RL. Stem cells: science, policy, and ethics. J Clin Invest. 2004;114:1364-70. doi:10.1172/JCI23549

6. Sanz AR, Carrión FS, Chaparro AP. Mesenchymal stem cells from the oral cavity and their potential value in tissue engineering. Periodontol 2000. 2015;67(1):251-67. doi: 10.1111/prd.12070

7. Dominici M, Le Blanc K, Mueller I, Slaper-Cortenbach I, Marini $F$, Krause $D$, et al. Minimal criteria for defining multipotent mesenchymal stromal cells. The International Society for Cellular Therapy position statement. Cytotherapy. 2006;8:315-17. doi: 10.1080/14653240600855905 
8. Gronthos S, Mankani M, Brahim J, Robey PG, Shi S. Postnatal human dental pulp stem cells (DPSCs) in vitro and in vivo. Proc Natl Acad Sci USA. 2000;97:13625-630. doi: 10.1073/pnas.240309797

9. Yang X, Walboomers XF, van den Beucken JJ, Bian Z, Fan M, Jansen JA. Hard tissue formation of STRO-1-selected rat dental pulp stem cells in vivo. Tissue Eng Part A. 2009;15:367-75. doi: 10.1089/ten. tea.2008.0133

10. Gronthos S, Brahim J, Li W, Fisher LW, Cherman N, Boyde A, et al. Stem cell properties of human dental pulp stem cells. J Dent Res. 2002:81:531-35. doi: 10.1177/154405910208100806

11. Zhang W, Walboomers XF, Wolke JG, Bian Z, Fan MW, Jansen JA. Differentiation ability of rat postnatal dental pulp cells in vitro. Tissue Eng. 2005;11:357-68. doi: 10.1089/ ten.2005.11.357

12. Iohara K, Imabayashi K, Ishizaka R, Watanabe A, Nabekura J, Ito $M$, et al. Complete pulp regeneration after pulpectomy by transplantation of CD105+ stem cells with stromal cell-derived factor-1. Tissue Eng Part A. 2011;17:1911-920. doi: 10.1089/ ten.TEA.2010.0615

13. Miura M, Gronthos S, Zhao M, Lu B, Fisher LW, Robey PG, et al. SHED: stem cells from human exfoliated deciduous teeth. Proc Natl Acad Sci USA. 2003;100:5807-812. doi: 10.1073/ pnas.0937635100

14. Fu X, Jin L, Ma P, Fan Z, Wang S. Allogeneic stem cells from deciduous teeth in treatment for periodontitis in miniature swine. J Periodontol. 2014;85:845-51. doi: 10.1902/ jop.2013.130254

15. Wang X, Sha XJ, Li GH, Yang FS, Ji K, Wen LY, et al. Comparative characterization of stem cells from human exfoliated deciduous teeth and dental pulp stem cells. Arch Oral Biol. 2012;57:12311240 doi: $10.1016 /$ j.archoralbio.2012.02.014

16. Zheng Y, Liu Y, Zhang CM, Zhang HY, Li WH, Shi S, et al. Stem cells from deciduous tooth repair mandibular defect in swine. J Dent Res. 2009;88:249-54. doi: 10.1177/0022034509333804

17. Behnia A, Haghighat A, Talebi A, Nourbakhsh N, Heidari F. Transplantation of stem cells from human exfoliated deciduous teeth for bone regeneration in the dog mandibular defect. World J Stem Cells. 2014;6:505-10. doi: 10.4252/wjsc

18. Morsczeck C, Götz W, Schierholz J, Zeilhofer F, Kühn U, Möhl C, et al. Isolation of precursor cells (PCs) from human dental follicle of wisdom teeth. Matrix Biol. 2005;24:155-65. doi: 10.1016/j. matbio.2004.12.004

19. Silvério KG, Davidson KC, James RG, Adams AM, Foster BL, Nociti $\mathrm{FH}$, et al. Wnt/B-catenin pathway regulates bone morphogenetic protein (BMP2)-mediated differentiation of dental follicle cells. J Periodontal Res. 2012;47:309-19. doi: 10.1111/j.16000765.2011.01433.x

20. Guo L, Li J, Qiao X, Yu M, Tang W, Wang H, et al. Comparison of odontogenic differentiation of human dental follicle cells and human dental papilla cells. PLoS One. 2013;8:e62332. doi: 10.1371/journal.pone.0062332

21. Huang GT, Al-Habib M, Gauthier P. Challenges of stem cell-based pulp and dentin regeneration: a clinical perspective. Endod Topics. 2013;28:51-60. doi: 10.1111/etp.12035

22. Sonoyama W, Liu Y, Fang D, Yamaza T, Seo BM, Zhang C, et al. Mesenchymal stem cellmediated functional tooth regeneration in swine. PLoS One. 2006;1:e79. doi: 10.1371/journal. pone.0000079

23. Zhang W, Zhang $X$, Ling J, Liu W, Zhang $X$, Ma J, et al. Proliferation and odontogenic differentiation of BMP2 gene-transfected stem cells from human tooth apical papilla: an in vitro study. Int J Mol Med. 2014;34:1004-12. doi: 10.3892/ijmm.2014.1862

24. Wang J, Liu B, Gu S, Liang J. Effects of Wnt/B-catenin signaling on proliferation and differentiation of apical papilla stem cells. Cell Prolif. 2012;45:121-31. doi: 10.1111/ j.13652184.2012.00806.x

25. Silvério KG, Rodrigues $T L$, Coletta RD, Benevides $L$, Da Silva JS, Casati MZ, et al. Mesenchymal stem cell properties of periodontal ligament cells from deciduous and permanent teeth. J Periodontol. 2010;81:1207-215. doi: 10.1902/ jop.2010.090729

26. Fukushima $H$, Kawanabe $N$, Murata $S$, Ishihara $Y$, Yanagita T, Balam TA, et al. SSEA-4 is a marker of human deciduous periodontal ligament stem cells. J Dent Res. 2012;91:955-60. doi: $10.1177 / 0022034512458123$

27. Ji K, Liu Y, Lu W, Yang F, Yu J, Wang $X$, et al. Periodontal tissue engineering with stem cells from the periodontal ligament of human retained deciduous teeth. I Periodontal Res. 2013;48:105-16. doi: 10.1111/j.1600-0765.2012.01509.x

28. Mitrano T, Grob M, Carrion F, Nova-Lamperti E, Luz P, Fierro F, et al. Culture and characterization of mesenchymal stem cells from human gingival tissue. J Periodontol. 2010;81:917-25. doi: 0.1902/jop.2010.090566

29. Park YJ, Cha S, Park YS. Regenerative applications using tooth derived stem cells in other than tooth regeneration: a literature review. Stem Cells Int. 2016;2016:9305986. doi: $10.1155 / 2016 / 9305986$

30. Nourbakhsh N, Soleimani M, Taghipour Z, Karbalaie K, Mousavi $S B$, Talebi Rabiei $F$, et al. Induced in vitro differentiation of neural-like cells from human exfoliated deciduous teeth-derived stem cells. Int J Dev Biol. 2011;55:189-95. doi: 10.1387/ ijdb.103090nn

31. Sedgley CM, Botero TM. Dental stem cells and their sources Dent Clin North Am. 2012;56:549-61. doi: 10.1016/ j.cden.2012.05.004

32. Sonoyama W, Liu Y, Yamaza T, Tuan RS, Wang S, Shi S, et al. Characterization of the apical papilla and its residing stem cells from human immature permanent teeth: a pilot study. J Endod. 2008;34:166-71. doi: 10.1016/j.joen.2007.11.021

33. Luan $X$, Ito $Y$, Dangaria S, Diekwisch TG. Dental follicle progenitor cell heterogeneity in the developing mouse periodontium. Stem Cells Dev. 2006;15:595-608. doi: 10.1089/scd.2006.15.595

34. Gay IC, Chen S, MacDougall M. Isolation and characterization of multipotent human periodontal ligament stem cells. Orthod Craniofac Res. 2007;10:149-60. doi: 10.1111/ j.16016343.2007.00399.x

35. Malhotra M. Induced Pluripotent Stem (iPS) cells in Dentistry: a review. Int J Stem Cells. 2016 Nov 30;9(2):176-185. doi: $10.15283 /$ ijsc16029

36. Gandia C, Arminan A, Garcia-Verdugo JM, Lledo E, Ruiz A, Minana $M D$, et al. Human dental pulp stem cells improve left ventricular function, induce angiogenesis, and reduce infarct size in rats 
with acute myocardial infarction. Stem Cells. 2008;26(3):63845. doi:10.1634/stemcells.2007-0484

37. Shen CY, Li L, Feng T, Li JR, Yu MX, Lu Q, et al. Dental pulp stem cells derived conditioned medium promotes Angiogenesis in Hindlimb Ischemia. Tissue Eng Regen Med. 2015;12(1):59-68. doi:10.1007/s13770-014-9053-7

38. Fang $C Z$, Yang $Y J$, Wang $Q H$, Yao $Y$, Zhang $X Y$, He $X H$. Intraventricular injection of human dental pulp stem cells improves hypoxic-ischemic brain damage in neonatal rats. PLoS One. 2013;8(6):e66748. doi:10.1371/journal.pone.0066748

39. Yamaza T, Kentaro A, Chen C, Liu Y, Shi $Y$, Gronthos S, et al. Immunomodulatory properties of stem cells from human exfoliated deciduous teeth. Stem Cell Res Ther. 2010;1(1):5. doi:10.1186/scrt5

40. Kanafi MM, Rajeshwari YB, Gupta S, Dadheech N, Nair PD, Gupta PK, et al. Transplantation of islet-like cell clusters derived from human dental pulp stem cells restores normoglycemia in diabetic mice. Cytotherapy. 2013;15(10):1228-236. doi: 10.1016/j. jcyt.2013.05.008

41. Yang R, Chen $M$, Lee $C H$, Yoon R, Lal S, Mao JJ. Clones of ectopic stem cells in the regeneration of muscle defects in vivo. PLOS One. 2010;5(10):e13547. doi: 10.1371/journal.pone.0013547

42. Graziano A, d'Aquino R, Laino G, Papaccio G. Dental pulp stem cells: a promising tool for bone regeneration. Stem Cell Rev. 2008;4(1):21-26. doi: 10.1007/s12015-008-9013-5

43. Reynolds AJ, Jahoda CA. Cultured human and rat tooth papilla cells induce hair follicle regeneration and fiber growth. Differentiation. 2014;72(9-10):566-75. doi: 10.1111/j.14320436.2004.07209010.x

44. Nishino Y, Ebisawa K, Yamada Y, Okabe K, Kamei Y, Ueda M. Human deciduous teeth dental pulp cells with basic fibroblast growth factor enhance wound healing of skin defect. J Craniofac Surg.
2011;22(2):438-42. doi: 10.1097/SCS.0b013e318207b507

45. Yamamura $Y$, Yamada $H$, Sakurai $T$, Ide $F$, Inoue $H$, Muramatsu $T$, et al. Treatment of salivary gland hypofunction by transplantation with dental pulp cells. Arch Oral Biol. 2013;58(8):935-42. doi: 10.1016/j. archoralbio.2013.02.015

46. Gomes JA, Geraldes Monteiro B, Melo GB, Smith RL, Cavenaghi Pereira da Silva $\mathrm{M}$, Lizier NF, et al. Corneal reconstruction with tissue-engineered cell sheets composed of human immature dental pulp stem cells. Invest Ophthalmol Vis Sci. 2010;51(3):1408-414. doi:10.1167/ iovs.09-4029

47. Cordeiro MM, Dong Z, Kaneko T, Zhang Z, Miyazawa M, Shi S, Smith AJ, Nör JE. Dental pulp tissue engineering with stem cells from exfoliated deciduous teeth. J Endod. 2008; 34: 962-969 doi: 10.1016/j.joen.2008.04.009

48. Suaid FF, Ribeiro FV, Rodrigues TL, Silvério KG, Carvalho MD, Nociti $\mathrm{FH}$, et al. Autologous periodontal ligament cells in the treatment of class II furcation defects: a study in dogs. J Clin Periodontol. 2011;38:491-98. doi: 10.1111/ j.1600-051X.2011.01715.x

49. Suaid FF, Ribeiro FV, Gomes TR, Silvério KG, Carvalho MD, Nociti $\mathrm{FH}$, et al. Autologous periodontal ligament cells in the treatment of Class III furcation defects: a study in dogs. J Clin Periodontol. 2012;39:377-84. doi: 10.1111/j.1600-051X.2012.01858.x

50. Okamoto T, Aoyama T, Nakayama T, Nakamata T, Hosaka T, Nishijo K, et al. Clonal heterogeneity in differentiation potential of immortalized human mesenchymal stem cells. Biochem Biophys Res Commun. 2002;295:354-61. doi: 10.1016/S0006291X(02)00661-7 